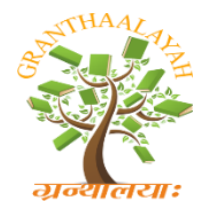

INTERNATIONAL JOURNAL OF RESEARCH GRANTHAALAYAH A knowledge Repository

Management

\title{
DISCUSSION ON THE HUMAN RESOURCES OF INDEPENDENT AUDIT IN VIETNAM
}

\author{
Phan Thanh Hai ${ }^{* 1}$ \\ ${ }^{* 1}$ Ph.D., Dean, Faculty of Accounting, Duy Tan University, Da Nang City, Vietnam
}

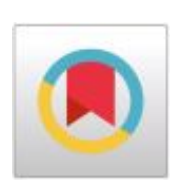

\begin{abstract}
The purpose of this study is to analyze the situation of human resources working in the independent auditing industry in Vietnam in the period 2010-2015. Through the qualitative research methodology, the author of the study has made some conclusions. The human resources in the independent auditing industry in Vietnam are still limited, both in terms of quantity and quality. These are no small challenges in the context of Vietnam has been and continues to integrate deeply into the international economy.
\end{abstract}

Keywords: Human Resources; Independent Auditing; International Integration; Vietnam.

Cite This Article: Phan Thanh Hai. (2017). "DISCUSSION ON THE HUMAN RESOURCES OF INDEPENDENT AUDIT IN VIETNAM." International Journal of Research - Granthaalayah, 5(10), 219-227. https://doi.org/10.29121/granthaalayah.v5.110.2017.2299.

\section{Introduction}

Human resources is a term that has been proposed by organizations and scientists for quite a long time with many complex points of view. Human resources can be construed as the place of reproduction, nurture and provision of human resources for development. This definition means showing the origin of human resources, in terms of the natural variation of the population and its impact on human resource mobility. Human resources are also construed as a direct element of the socio-economic development process, which is the whole specific people involved in the labor process. Within the framework of the article, the author uses this definition to easily obtain specific and quantifiable assessments of human resources in the independent audit service in Vietnam.

\section{Literature Review}

In recent years, there have been many studies that have mentioned the role and significance of human resources for improving competitiveness, sustainability and development, efficiency and quality in the business, sector. For example, Thorne's research shows that high-performing firms are characterized by high performance such as high market share, high productivity, low production costs (Thorne, 2004). The research of WEF (2004) suggests that there are two groups 
of factors influencing the company's competitiveness including: internal factors such as organizational capacity; capacity of equipment, tools; human resources quality; financial capacity; business size; marketing capacity; Research and development capacity. Meanwhile, external factors may affect the company's competitiveness including: market; institutions and policies; support; human resources qualifications; Infrastructure system.

For research in the independent auditing field, some studies also dealt with the role of human resources. As illustrated by Newbert's research (2008), there are five main sources which are able to the auditing company's competitiveness including: financial resources, human resources, intellectual resources, organizational resources, and physical resources. Research implemented by Phan Đ. D (2015) has identified that among 12 factors affecting the quality of auditing services provided to the market, there is the quality of staff and managers; Human Resources. Previous research implemented by Đoan X. T (2006) also identified the ability of organizations to manage business operation, management, ability to update information, the ability to cooperate with relevant enterprises, ensuring the credibility in business, the quality of the management staff, are factors affecting the auditing company's competitiveness.

From the above analysis, we can see that human resources is an extremely important factor having decisive influence to competitiveness, the quality of services that an auditing company can provide to customers. On a large scope, the quality and quantity of human resources in the audit field will be a key factor for the survival, stability and sustainable development of the audit field; especially, in the period of international integration, there are many advantages but not less difficulties and challenges at present.

\section{Materials and Methods}

The data collected by the author is based on data from various reports published by the Ministry of Finance and the Vietnam Association of Certified Public Accountants (VACPA) between 2010 and 2016. On the basis of This data, the author conducts the analysis, selection and calculation, presented by indicators, factors related to the situation of human resources in the field of independent audit in Vietnam. Two aspects of the article's author that go into the analysis are the quantity and quality of human resources.

\section{Result and Discussion}

Based on using qualitative research method with the reliable secondary data published by the Ministry of Finance, VACPA, the author of this article would like to highlight the current situation of human resources in the independent audit service in our country last time including two main aspects: quantity and quality as follows:

\section{- The number of audit practitioners, skilled employees working in the field of the independent audit.}

According to statistics, in the last five years (2010-2015), skilled employees and audit practitioners working in the field of independent audit in our country are constantly increasing. However, the growth rate in terms of scale of the following year compared to the previous year 
was not large and dramatic. This situation is reflected in the figures in the table 1 and figure 1 as follows:

Table 1: Volatility of human resources audit in Vietnam

\begin{tabular}{|l|l|l|l|l|l|l|l|l|l|l|l|l|}
\hline \multicolumn{1}{|c|}{ Year } & \multicolumn{2}{c|}{$\mathbf{2 0 1 0}$} & \multicolumn{2}{c|}{$\mathbf{2 0 1 1}$} & \multicolumn{2}{c|}{$\mathbf{2 0 1 2}$} & \multicolumn{2}{c|}{$\mathbf{2 0 1 3}$} & \multicolumn{2}{c|}{$\mathbf{2 0 1 4}$} & \multicolumn{2}{c|}{$\mathbf{2 0 1 5}(*)$} \\
\hline Form of company & Quantity & $\mathbf{( \% )}$ & Quantity & $(\boldsymbol{\%})$ & Quantity & $(\boldsymbol{\%})$ & Quantity & $(\boldsymbol{\%})$ & Quantity & $(\boldsymbol{\%})$ & Quantity & $(\boldsymbol{\%})$ \\
\hline 1. Foreign audit firms & $\mathbf{2 , 2 5 6}$ & $\mathbf{2 5 . 9}$ & $\mathbf{2 , 5 1 9}$ & $\mathbf{2 6 . 1}$ & $\mathbf{2 , 6 3 2}$ & $\mathbf{2 5 . 6}$ & $\mathbf{2 , 6 1 3}$ & $\mathbf{2 4 . 7}$ & $\mathbf{2 , 8 7 3}$ & $\mathbf{2 5 . 9}$ & $\mathbf{2 , 8 2 5}$ & $\mathbf{2 4 . 7}$ \\
\hline Employees (none CPA) & 2,045 & 23.5 & 2,256 & 23.4 & 2,329 & 22.6 & 2,444 & 23.1 & 2,653 & 23.9 & 2,558 & 22.4 \\
\hline CPA & 211 & 2.4 & 263 & 2.7 & 303 & 2.9 & 169 & 1.60 & 220 & 1.9 & 267 & 2.3 \\
\hline 2. Vietnam audit firms & $\mathbf{6 , 4 3 0}$ & $\mathbf{7 4 . 0}$ & $\mathbf{7 , 1 1 9}$ & $\mathbf{7 3 . 8 6}$ & $\mathbf{7 , 6 3 7}$ & $\mathbf{7 4 . 3}$ & $\mathbf{7 , 9 3 5}$ & $\mathbf{7 5 . 2}$ & $\mathbf{8 , 1 9 8}$ & $\mathbf{7 4 . 0}$ & $\mathbf{8 , 5 8 9}$ & $\mathbf{7 5 . 2}$ \\
\hline Employees (none CPA) & 5,394 & 62.1 & 5,967 & 61.9 & 6,386 & 62.1 & 6,704 & 63.5 & 6,890 & 62.2 & 7,147 & 62.6 \\
\hline CPA & 1,036 & 11.9 & 1,152 & 11.9 & 1,251 & 12.1 & 1,231 & 11.6 & 1,308 & 11.8 & 1,442 & 12.6 \\
\hline Total & $\mathbf{8 , 6 8 6}$ & $\mathbf{1 0 0}$ & $\mathbf{9 , 6 3 8}$ & $\mathbf{1 0 0}$ & $\mathbf{1 0 , 2 6 9}$ & $\mathbf{1 0 0}$ & $\mathbf{1 0 , 5 4 8}$ & $\mathbf{1 0 0}$ & $\mathbf{1 1 , 0 7 1}$ & $\mathbf{1 0 0}$ & $\mathbf{1 1 , 4 1 4}$ & $\mathbf{1 0 0}$ \\
\hline CPA & 1,247 & 14.35 & 1,415 & 14.68 & 1,554 & 15.13 & 1,400 & 13.27 & 1,528 & 13.80 & 1,709 & 14.97 \\
\hline Employees (none CPA) & 7,439 & 85.65 & 8,223 & 85.32 & 8,715 & 84.87 & 9,148 & 86.73 & 9,543 & 86.20 & 9,705 & 85.03 \\
\hline
\end{tabular}

(*) As of June 2016

Based on this data, we can see that in terms of quantity, as of June 2016, Vietnam audit firms consist of 11,414 people including 1,709 CPA. Preliminary statistic shows that for each audit firm, there are 80.3 people, of which 12.04 people are auditors registered for practice; The proportion of CPA in the total number of employees working in the audit field is $14.97 \%(1,709$ auditors/11,414 people). These figures show that the size of human resources of Vietnam audit firms is still low.

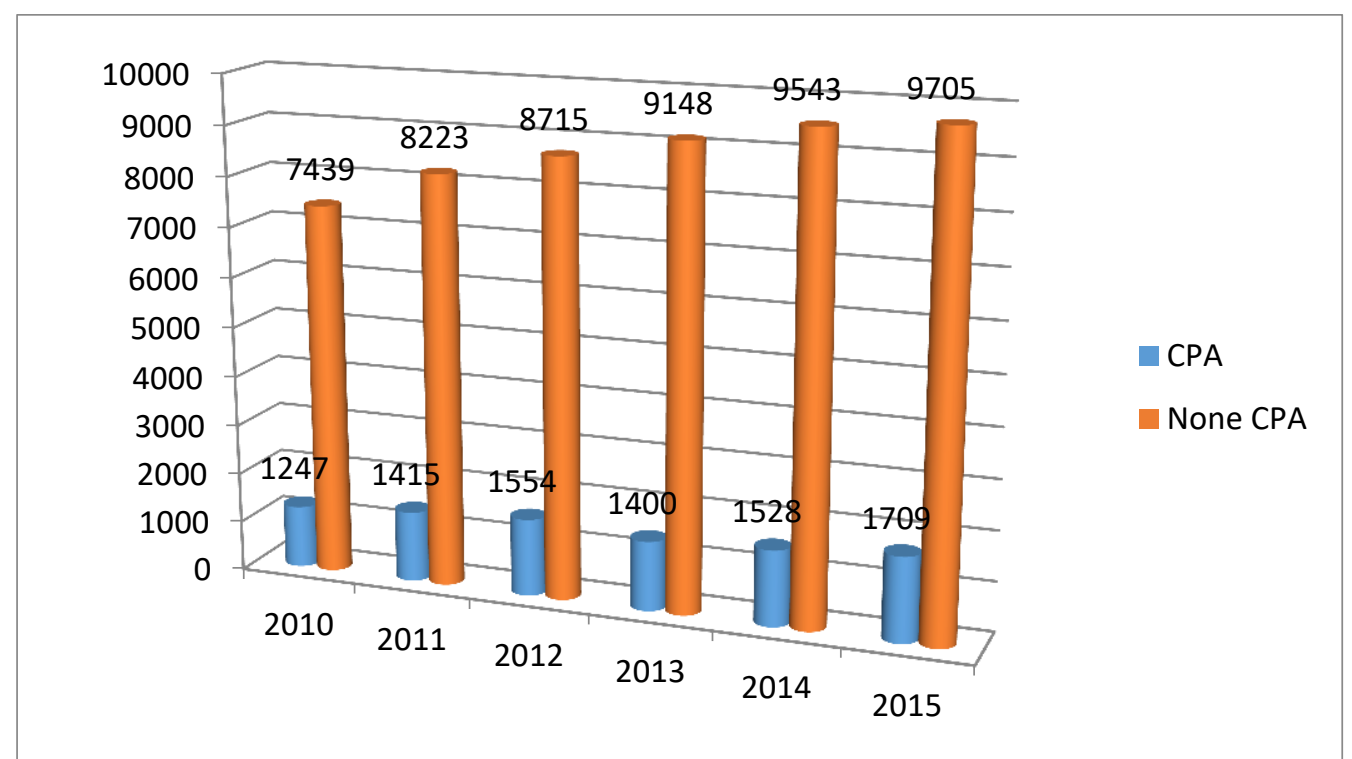

Figure 1: Number of human resources audited in Vietnam from 2010-2015

Particularly, when analyzing at a more detailed level as in Table 2 below, it can be seen that audit practitioners/total employees and average auditors/audit firms is quite low. Especially in the audit firms which are not members of the international audit firms, the average auditors/ audit 
firms is 7.52, but there are up to 40 audit firms which just meet the minimum level of 5 audit practitioners, 5 audit firms with the number of 6-9 auditors, 17 audit firms with the number of 10-15 auditors. 20 audit firms with the number of 16-28 auditors and only 10 audit firms with the number of auditors at the level of 29-76 peoples as stipulated by law. (VACPA, 2016).

Table 2: The structure of human resources audit in Vietnam in 2016

\begin{tabular}{|c|c|c|c|c|c|c|}
\hline Forms of enterprises & $\begin{array}{l}\text { Number of } \\
\text { independen } \\
\text { audit firms }\end{array}$ & $\begin{array}{l}\text { Number } \\
\text { of skilled } \\
\text { employees }\end{array}$ & $\begin{array}{l}\text { Number } \\
\text { of } \\
\text { auditors }\end{array}$ & $\begin{array}{c}\text { Total } \\
\text { employees }\end{array}$ & $\begin{array}{c}\text { Ratio of } \\
\text { auditors/employees } \\
(\%)\end{array}$ & $\begin{array}{c}\text { Average ratio of } \\
\text { auditors/audit } \\
\text { firms }\end{array}$ \\
\hline $\mathbf{A}$ & (1) & (2) & (3) & $(4)=(2)+(3)$ & $(5)=(3) /(4)$ & $(6)=(3) /(1)$ \\
\hline 1. Foreign audit firms & 10 & 2,558 & 267 & 2,825 & 9.45 & 26.70 \\
\hline $\begin{array}{l}\text { Enterprises with } 100 \% \\
\text { foreign capital }\end{array}$ & 3 & 1,987 & 176 & 2,163 & 8.14 & 58.67 \\
\hline Invested enterprises & 7 & 571 & 91 & 662 & 13.75 & 13.00 \\
\hline 2. Vietnam audit firms & 132 & 7,147 & 1.442 & 8,589 & 16.79 & 10.92 \\
\hline Net works firms & 15 & 2,345 & 435 & 2,780 & 15.65 & 29.00 \\
\hline Association members & 12 & 977 & 205 & 1,182 & 17.34 & 17.08 \\
\hline Correspondent firms & 1 & 96 & 20 & 116 & 17.24 & 20.00 \\
\hline Other & 104 & 3,729 & 782 & 4,511 & 17.34 & 7.52 \\
\hline Total & 142 & 9,705 & 1,709 & 11,414 & $\mid 14.97$ & $\mid 12.04$ \\
\hline
\end{tabular}

Accordingly, based on the above analysis data, it is easy to see that the number of human resources in the independent audit industry is relatively small. In the period of deepening integration, the number of audit practitioners has not reached 2,000 people yet, while actually the number of audits who are granted with CPA certificate by the end of June 2016 is 3,837 people (2,128 people have CPA certificates but do not work in the field of the independent audit or practice registration, accounting for $55.45 \%$ ).

Compared to the AEC region, with the current number of audit practitioners, Vietnam accounts for only $1.9 \%$ of the number of audit practitioners in the ASEAN region (Đang V. T, 2016). A very modest ratio can show the current status of the number of staff directly engaged in the independent audit service in our country today.

\section{- The quality of audit practitioners, skilled employees working in the field of independent audit}

Besides quantitative factors as analyzed above, the human resource of the independent audit service in Vietnam is still relatively low in terms of quality. This is reflected in many factors such as age, length of service (years of experience) is still low; The number of diplomas and certificates related to the professional qualifications of the audits is quite low, staff and auditors who know and use 2-3 foreign languages fluently is rather low. Table 3 below shows the number of certificates and professional qualifications that human resources in the independent audit industry have achieved in the last two years. Of which the data in column 2015 has been calculated up to June 2016. 
Table 3: Professional qualifications of human resources auditin Vietnam between 2015 and 2016

\begin{tabular}{|l|l|l|l|l|}
\hline \multirow{2}{*}{ Norms of the professional qualifications } & \multicolumn{2}{|c|}{ June $\mathbf{2 0 1 6}$} & \multicolumn{2}{|c|}{ June $\mathbf{2 0 1 5}$} \\
\cline { 2 - 6 } & Quantity & \multicolumn{1}{|c|}{$\%$} & Quantity & \multicolumn{1}{|c|}{$\%$} \\
\hline Total employees & $\mathbf{1 1 , 4 1 4}$ & $\mathbf{1 0 0}$ & $\mathbf{1 1 , 0 7 1}$ & $\mathbf{1 0 0}$ \\
\hline None CPA & 9,705 & 85.03 & 9,543 & 86.19 \\
\hline The number of employees certified CPA Vietnam & $\mathbf{1 , 7 9 7}$ & $\mathbf{1 5 . 7 4}$ & $\mathbf{1 , 6 4 7}$ & $\mathbf{1 4 . 8 8}$ \\
\hline - Vietnamese people & 1,772 & 15.52 & 1,617 & 14.61 \\
\hline -Foreigners & 25 & 0.22 & 30 & 0.27 \\
\hline Number of people who have been granted CPA at the audit firms & $\mathbf{1 , 7 0 9}$ & $\mathbf{1 4 . 9 7}$ & $\mathbf{1 , 5 2 8}$ & $\mathbf{1 3 . 8 0}$ \\
\hline -Vietnamese people & 1,684 & 14.75 & 1,500 & 13.55 \\
\hline -Foreigners & 25 & 0.22 & 28 & 0.25 \\
\hline Number of people who are granted international auditing certificate & $\mathbf{2 6 6}$ & $\mathbf{2 . 3 3}$ & $\mathbf{2 4 0}$ & $\mathbf{2 . 1 7}$ \\
\hline -Vietnamese people & 237 & 2.08 & 206 & 1.86 \\
\hline -Foreigners & 29 & 0.25 & 34 & 0.31 \\
\hline Number of people issued Accounting Practice Certificate & $\mathbf{1 0 7}$ & $\mathbf{0 . 9 4}$ & $\mathbf{6 0}$ & $\mathbf{0 . 5 4}$ \\
\hline Number of people issued Valuer Certificate & $\mathbf{3 4 2}$ & $\mathbf{3 . 0 0}$ & $\mathbf{3 1 5}$ & $\mathbf{2 . 8 5}$ \\
\hline $\begin{array}{l}\text { Number of peoples issued a Certificate for Practising Service on Tax } \\
\text { Procedure }\end{array}$ & $\mathbf{7 0 1}$ & $\mathbf{6 . 1 4}$ & $\mathbf{6 8 9}$ & $\mathbf{6 . 2 2}$ \\
\hline
\end{tabular}

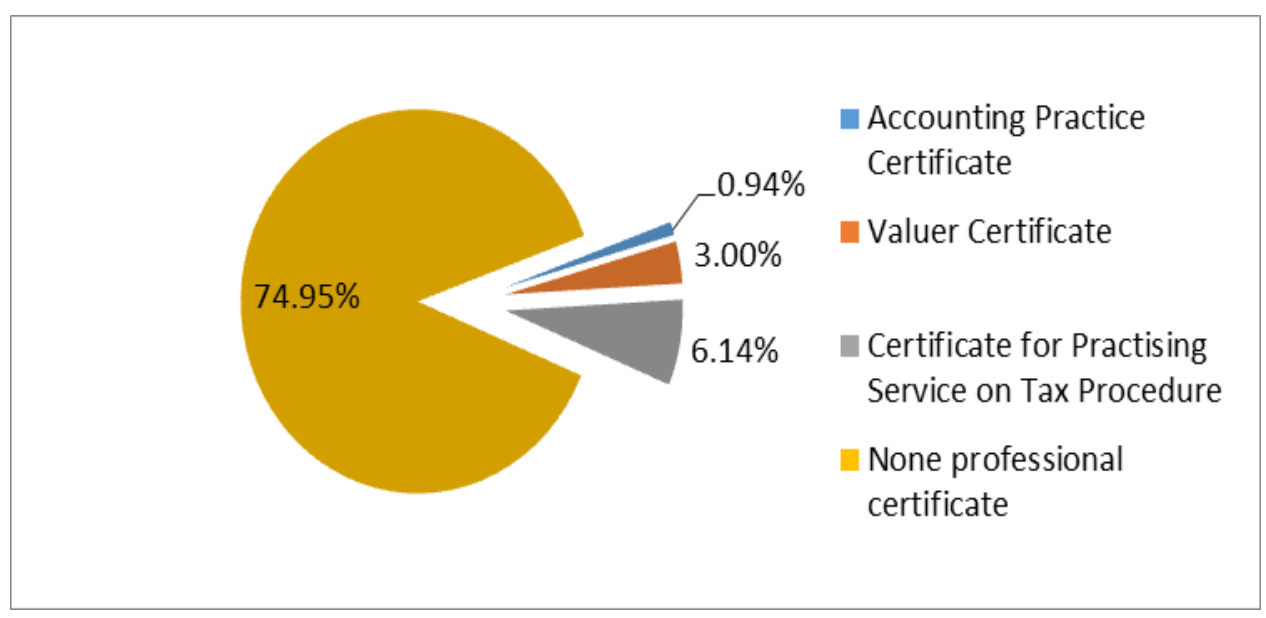

Figure 2: Structure of human resources audit in Vietnam based on professional certificates

According to tables 3 and 2, it can easily be seen that among the 11.414 people working in the independent audit service, the numbers of people who have not yet achieved the professional qualifications in auditing, accounting, taxation, valuation, etc for the related work is quite minimal. Currently up to $74.95 \%$ of people do not have elementary qualifications, exclusive of the calculation presented above is only relative because one person may own multiple professional certificates at the same time.

In the scope of this article, in addition to the vocational qualifications and practicing certificates related to the profession, to measure the professional qualification of human resources, the 
author also considers the average productivity per an auditor. This criterion is calculated by (=) Sales divided by (/) Number of audit practitioners (or number of skilled employees)

Table 4: Average productivity of audit practitioners in the period 2010-2015

Unit : million VND

\begin{tabular}{|l|l|l|l|l|l|l|}
\hline Year & $\mathbf{2 0 1 0}$ & $\mathbf{2 0 1 1}$ & $\mathbf{2 0 1 2}$ & $\mathbf{2 0 1 3}$ & $\mathbf{2 0 1 4}$ & $\mathbf{2 0 1 5}$ \\
\cline { 1 - 6 } $\begin{array}{l}\text { Forms of enterprises } \\
\text { audit service }\end{array}$ & $\mathbf{2 , 2 0 0}$ & $\mathbf{2 , 3 4 3}$ & $\mathbf{2 , 4 3 9}$ & $\mathbf{2 , 9 6 9}$ & $\mathbf{2 , 9 9 9}$ & $\mathbf{3 , 0 0 2}$ \\
\hline $\begin{array}{l}\mathbf{1 .} \text { Average productivity of auditors in foreign audit } \\
\text { firms }\end{array}$ & $\mathbf{6 , 0 4 6}$ & $\mathbf{6 , 1 0 5}$ & $\mathbf{5 , 9 2 0}$ & $\mathbf{1 1 , 6 7 8}$ & $\mathbf{9 , 6 3 2}$ & $\mathbf{8 , 7 9 5}$ \\
\hline Enterprises with 100\% foreign capital & 6,378 & 6,716 & 6,498 & 15,148 & 14,166 & 11,960 \\
\hline Invested enterprises & 3,047 & 1,848 & 2,329 & 2,402 & 2,566 & 2,674 \\
\hline $\begin{array}{l}\text { 2. Average productivity of auditors in Vietnam audit } \\
\text { firms }\end{array}$ & $\mathbf{1 , 4 1 7}$ & $\mathbf{1 , 4 8 4}$ & $\mathbf{1 , 5 9 5}$ & $\mathbf{1 , 7 7 3}$ & $\mathbf{1 , 8 8 4}$ & $\mathbf{1 , 9 2 9}$ \\
\hline Net works firms & 2,342 & 2,565 & 2,691 & 2,985 & 3,339 & 3,173 \\
\hline Association members & 1,642 & 1,697 & 1,485 & 1,552 & 1,587 & 1,540 \\
\hline Correspondent firms & 1,589 & 2,092 & 2,218 & 2,279 & 1,409 & 1,377 \\
\hline Other & 860 & 894 & 1,034 & 1,101 & 1,176 & 1,353 \\
\hline Total & $\mathbf{4 , 6 2 9}$ & $\mathbf{4 , 6 2 1}$ & $\mathbf{4 , 3 2 5}$ & $\mathbf{9 , 9 0 5}$ & $\mathbf{7 , 7 4 8}$ & $\mathbf{6 , 8 6 6}$ \\
\hline
\end{tabular}

According to the above analysis, it can be seen that on average every year, a audit practitioner belongs to the company's workforce contributing 2-3 billion VND to the audit firms. However, this productivity difference is quite clear (8 to 10 times) between the groups of foreign enterprises, especially 03 Enterprises with $100 \%$ foreign capital (E \& Y, KPMG, Deloitte) compared with the Vietnam enterprises.

Table 5: Average productivity of skilled employees in the period 2010-2015

\begin{tabular}{|l|l|l|l|l|l|c|c|}
\hline $\begin{array}{l}\text { Sl. } \\
\text { No }\end{array}$ & Norms & $\mathbf{2 0 1 0}$ & $\mathbf{2 0 1 1}$ & $\mathbf{2 0 1 2}$ & $\mathbf{2 0 1 3}$ & $\mathbf{2 0 1 4}$ & $\mathbf{2 0 1 5}$ \\
\hline 1 & Average revenue of international audit firms & $1,275,746$ & $1,605,721$ & $1,793,840$ & $1,973,661$ & $2,118,939$ & $2,348,270$ \\
\hline 2 & Average revenue of Vietnam audit firms & $1,467,973$ & $1,710,127$ & $1,995,892$ & $2,182,965$ & $2,464,195$ & $2,781,295$ \\
\hline $\mathbf{3}$ & The total revenue & $\mathbf{2 , 7 4 3 , 7 1 9}$ & $\mathbf{3 , 3 1 5 , 8 4 8}$ & $\mathbf{3 , 7 8 9 , 7 3 2}$ & $\mathbf{4 , 1 5 6 , 6 2 6}$ & $\mathbf{4 , 5 8 3 , 1 3 4}$ & $\mathbf{5 , 1 2 9 , 5 6 5}$ \\
\hline $\mathbf{4}$ & Number of skilled employees & $\mathbf{8 , 6 8 6}$ & $\mathbf{9 , 6 3 8}$ & $\mathbf{1 0 , 2 6 9}$ & $\mathbf{1 0 , 5 4 8}$ & $\mathbf{1 1 , 0 7 1}$ & $\mathbf{1 1 , 4 1 4}$ \\
\hline $4 a$ & - International audit firms & 2,256 & 2,519 & 2,632 & 2,613 & 2,873 & 2,825 \\
\hline $4 b$ & -Vietnam audit firms & 6,430 & 7,119 & 7,637 & 7,935 & 8,198 & 8,589 \\
\hline $\mathbf{5}$ & Average productivity of skilled employees $\mathbf{( 3 / 4 )}$ & $\mathbf{3 1 5 . 9}$ & $\mathbf{3 4 4 . 0}$ & $\mathbf{3 6 9 . 0}$ & $\mathbf{3 9 4 . 1}$ & $\mathbf{4 1 4 . 0}$ & $\mathbf{4 4 9 . 4}$ \\
\hline $5 \mathrm{a}$ & - International audit firms $(1 / 4 \mathrm{a})$ & 565.5 & 637.4 & 681.6 & 755.3 & 737.5 & 831.2 \\
\hline $5 \mathrm{~b}$ & - Vietnam audit firms (2/4b) & 228.3 & 240.2 & 261.3 & 275.1 & 300.6 & 323.8 \\
\hline
\end{tabular}


Thus, based on Table 5, it can be seen that the average productivity of skilled employees in the past was between 315-450 million VND/employee/year (approximately 22,500 USD/ year). This is relatively high productivity in comparison to other industries in the society, but in the field of independent audit, this productivity in our country is generally much lower than in other countries in the same region, especially Singapore, Thailand, Indonesia, Malaysia, etc.

\section{Conclusion and Recommendations}

Thus, based on the data and analysis presented above, it can be seen that though human resources for the independent audit service in Viet Nam in the past time has made many breakthroughs and clear improvement, but basically in terms of quantity and quality, there are still many basic restrictions. This is evidenced by the fact that the number of special human resources of audit practitioners is still low, the average productivity is not high and the professional qualifications shown by the national and international professional diplomas and certificates are still low, the rate of auditors has passed the certificate but not working in the audit field is rather high $(55.45 \%) \ldots$

This is a big challenge while Vietnam has been deeply integrating into the international economy, joining in the important organizations such as ASEAN Economic Community (AEC), Trans-Pacific Partnership Agreement (TPP), and Free Trade Agreement (FTA).

Based on the current situation and some limitations on the human resources of the independent audit service in the last 5 years, the author presents solutions with specific recommendations as follows. :

\section{For the Government and ministerial levels (Ministry of Finance, Ministry of Education and Training.)}

Continue reviewing and finishing, set up the legal framework in the fields of finance, taxation, accounting and auditing, etc in full accordance with international practice to facilitate the sustainable development of services provided by audit firms.

Study and issue sub-law documents on the implementation of service commitments in international and regional organizations such as Bilateral Trade Association (BTA), General Agreement on Trade in Services (GATS) and ASEAN Framework Agreement on Services (AFAS) for auditing services. Promulgate regulations of preferences on procedures for exit, entry, residence and licences of accounting and auditing specialists providing transnational audit services.

Invest in and support universities and institutes in the course of audit training. Encourage training cooperation with prestigious associations in the world to carry out the training of certificates and qualifications such as ACCA, CPA Australia, ICAEW, etc.

Stronger transfer of monitoring and evaluation of quality of work, professional ethics of relevant professional associations such as Vietnam Association of Certified Public Accountants (VACPA), Vietnam Association of Accountants and Auditors (VAA) 
Organize exams for practising certificate quarterly and execute in large areas of the 3 regions of the country instead of only implement in Ho Chi Minh City and Ha Noi twice a year at present.

\section{For Vietnam Association of Certified Public Accountants (VACPA), Vietnam Association of Accountants and Auditors (VAA)}

Strengthen and expand cooperation with professional organizations in the region and in the world; Carry out the negotiation in order to reach the recognition and standardization of Vietnam's practising certificates in other countries, with the highest priority given to the implementation of agreements on recognition of accounting and audit profession in the AEC area (Mutual Recognition Agreement).

Together with the ministries, branches and audit firms, research and develop a set of standard manuals for training new personnel; curricula, materials for training and review of practising certificates based on the training programs of prestigious professional associations.

Support the audit firms, universities and institutes in training auditors, skilled employees as well as students studying accounting and auditing sector.

Recommend to the Ministry of Finance on modification of the training program for auditors and practising accountants. Separate the current training and certification functions so as to ensure the independence, objectivity and improvement of the professionalism and quality of the trainees.

\section{For audit firms}

An audit firm is a participant in the integration process of AEC, TPP and FTA directly and actively. In order to improve the quantity and quality of human resources of their own businesses, the enterprises should attach special importance to the following tasks:

Pay special attention to the training and fostering to raise the qualifications, capacity and professional ethics of the employees. Set up good compensation \& benefits package in order to retain good employees and attract human resources to work, both Vietnamese and foreigners. Recruit highly skilled foreign employees, especially neighboring countries in Southeast Asia such as Singapore, Malaysia, Thailand, etc to work to both expand the transnational service to that country and make use of internal training to improve the quality of Vietnamese human resources.

Focus on investment, construction and continuous improvement of business strategies of enterprises by researching the market, provide services, diversify the products and services provided on a stable maintenance basis. and the dramatic development of the quality of the auditors, managers in the enterprise.

Actively seek partners, negotiate to join associations; link with reputable international audit firms to inherit business experience and build strategy, orientation for business development in the coming time. Being a member of international auditing firms is considered as a proper 
solution to enhance prestige and brand in business competition; enhance the attractiveness of auditing apprentice. Obviously, in order to achieve this, the audit firms should review and compare the criteria and standards set by the international audit firms; establish a sustainable strategy to achieve those criteria and standards.

\section{References}

[1] Government of Vietnam. (2013). "Decision 480/qd-ttg dated 18/03/2013 approving the accounting and auditing strategy to 2020, vision 2030". . Retrieved from : http://vbqppl.mpi.gov.vn/en-us/Pages/default.aspx?lv=54b8b70b-20e2-4ed0-9b1a7d4d9d7f7a19\&list=document

[2] Đoan X.T. (2006). "Raising the competitiveness of the auditing company in vietnam". Research subject at the academic level, Hanoi Financial Academy.

[3] Đang V. T. (2016). "Vietnam accounting auditors: worry about the quality of human resources, vietnam financial times". Retrieved from :

http://thoibaotaichinhvietnam.vn/pages/xa-hoi/2016-05-27/ke-toan-kiem-toan-viet-nam-noi-lochat-luong-nguon-nhan-luc-32047.aspx

[4] Newbert, S. (2008). "Value, rareness, competitive advantage, and performance: a conceptuallevel empirical investigation of the resource-based view of the firm". Strategic Management Journal, 745-768. https://doi.org/10.1002/smj.686

[5] Phan Đ. D. (2015). the factors affecting audit quality of audit firms in vietnam oriented to strengthen competitive capability in international integration conditions. Economics Philosophy Doctor Thesis, University of Economics of Ho Chi Minh City.

[6] Thorne, F. (2004). Measuring the competitiveness of irish agriculture (1996-2000). Teagasc Publisher. Retrieved from : http://t-stor.teagasc.ie/handle/11019/1223

[7] VACPA. (2010-2016). Summary report of operation and operation direction for the years 20102016 of independent auditors.

[8] VACPA. (2010-2016). Annual meeting of directors of audit firms".

[9] World Economic Forum. (2004), the global competitiveness report. Retrieved from : www.weforum.org

*Corresponding author.

E-mail address: phanthanhhai@ duytan.edu.vn 